\title{
What Is the Future of Adult Training?-A Systematic Literature Review
}

\author{
Käthe Schneider*, Rebekka Langen \\ Institute of Education and Culture, Friedrich-Schiller-University Jena, Jena, Germany \\ Email: *k.schneider@uni-jena.de
}

How to cite this paper: Schneider, K., \& Langen, R. (2021). What Is the Future of Adult Training?-A Systematic Literature Review. Psychology, 12, 236-254. https://doi.org/10.4236/psych.2021.122015

Received: January 12, 2021

Accepted: February 16, 2021

Published: February 19, 2021

Copyright (c) 2021 by author(s) and Scientific Research Publishing Inc. This work is licensed under the Creative Commons Attribution International License (CC BY 4.0).

http://creativecommons.org/licenses/by/4.0/

\begin{abstract}
As digitalization of work continues to progress, workers have to face new skill requirements corresponding to the 21 st century. This creates a need for adaptation of adult training. The present review deals with the question of what is known about future adult training in the scientific literature. A sample of 16 articles identified from 2.461 screened abstracts was analyzed using a combination of quantitative frequency analysis and qualitative content analysis. The results show that future adult trainings should focus on promoting psychomotor, cognitive and interpersonal skills, as well as theoretical and non-cognitive skills in workers. To achieve a certain skill level, instruction in combination with mostly technically supported activating methods such as simulations, games or role plays are in demand. Skills that are more resilient to automation such as intrapersonal, meta- and existential skills are rarely or not at all found in the literature and should be more researched in the future.
\end{abstract}

\section{Keywords}

Training, Future Skills, Learning Technologies, Foresight Research, Digitalization

\section{Introduction}

The world of work has undergone some changes in recent decades as digitalization progresses. More and more tasks can be automated by using a wide range of technologies. In order to continue to exist in the labour market, workers from different sectors must therefore adapt their skills to the demands of the 21st century (Leopold, Ratcheva, \& Zahidi, 2018). In this study, we will examine how this affects the training landscape of adult education.

Based on Bullough, de Luque, Abdelzaher, and Heim (2015), the factors that contribute to effective education and training consist of goals and program ele- 
ments: Goals are understood as independent variables that steer the choice and design of program elements. Program elements influence a program's effectiveness and consist, for example, of trainers, curriculum, delivery, and wrap-around services (Bullough et al., 2015). Within this framework, there are three components that moderate the relationship between goals and program elements: These are: 1) individual characteristics of program participants (human factors, such as capabilities), 2) contextual characteristics of the environment in which the program is implemented (e.g. culture), and 3) funding (from donors, grants, or tuition). These three components influence a program's effectiveness in achieving its goals (Bullough et al., 2015). Following Steiner (1988), training is defined as non-intended, guided learning.

As changing technologies are key drivers in educational change (Attwell, 2007), we assume that in the future, goals and program elements of adult training will be transformed. In the current study, we aim at investigating state-of-the-art research on the problems, target groups, goals and program elements of future training. Here we are making a systematic literature review.

An important factor that affects the selection of program elements in training is the goal (Bullough et al., 2015). Understood as an educational aim it “... is a conceived psychic disposition (or a conceived psychic dispositional network) ... that is wanted, attempted to create or called for in the one to be educated" (Brezinka, 1981: p. 150, italics in original text). Goals can be derived from socially desired and required competencies and skills in a person to be educated (ibid.). Due to an assumed change of future required and desired competencies and skills, as the following models of core competencies and skills needed in the future show, we come to hypothesize that the program elements will change.

Loshkareva, Luksha, Ninenko, Smagin, and Sudakov (n.d.) developed a model of 21st century skills, visually represented as a three-layered matryoshka doll: The meta-skills and existential skills are at the core of the doll, accompanied by crosscontextual skills in the middle and surrounded by the context-specific skills that form the outer layer. Context-specific skills are related to hard skills developed in a specific context (ibid.). Compared to soft skills, hard skills are based on standardized procedures and allow us to measure a goal. An example is the physical skill of driving a car. Cross-contextual skills are "applied in a larger domain", (ibid., p. 76), for example, the ability to read. Meta-skills are "different modes of operating objects in our mind or in the physical world [...]" (ibid., p. 76). A logical-mathematical mode represents such a meta-skill. Existential skills are foundational skills. They can "be universally applied throughout the lifetime and in different living contexts" (ibid., p. 76). For example, these skills refer to the ability to set goals and achieve them (will-power).

Another study related to developing transferable knowledge and skills in the 21st century is being conducted by the National Research Council (2012). The council defines and clarifies the knowledge and skills they referred to as "21st century competencies" (National Research Council, 2012: p. 23) and distinguishes three categories of competence: "cognitive", "intrapersonal" and "interper- 
sonal" (National Research Council, 2012: p. 3). "The cognitive domain involves reasoning and memory; the intrapersonal domain involves the capacity to manage one's behavior and emotions to achieve one's goals [...]; and the interpersonal domain involves expressing ideas, and interpreting and responding to messages from others" (National Research Council, 2012: p. 3). The National Research Council (2012) focuses on the first three second-order cognitive factors, fluid intelligence, crystallized intelligence and retrieval ability, as they are most closely related to 21st century skills. Furthermore, the National Research Council (2012) modeled intrapersonal competencies according to three of the five personality dimensions, openness, conscientiousness and neuroticism, while they relate the remaining two dimensions, extraversion and agreeableness, to the interpersonal competencies.

The study resulted in the following cluster of 21st century competencies within the three domains driven by the main ability, respectively personality factors (see Table 1) (National Research Council, 2012):

For the question of future competencies required by various occupations, it is helpful to relate Bloom's (1956) taxonomy of educational objectives, which is basically a taxonomy of human activity, to the risk of future automation. Based on an interview that was conducted with Charles Fadel, Loshkareva et al. (n.d.) conclude that the progress of technology would affect the psychomotor area, which does not imply the most interventions in other areas, followed by the cognitive area, while the technology risk in the affective area would be minimal (Loshkareva et al., n.d.). In the digitized environment, the demand for interaction with other people on the emotional level will still be high. As for the cognitive area and the medium-level impact of technology on it, computer systems can already substitute for lower level cognitive processes. Referring to the higher cognitive processes of analysis or generalization, for example, studies show that neural networks already cope with generalizing experience and analyzing new information (Loshkareva et al., n.d.). This observation of Loshkareva et al. (n.d.) supports the statement of other studies which assume that the way how digitization proceeds is skill-biased (e.g., Acemoglu, 2002; Acemoglu \& Autor, 2011).

The international future of jobs report offers an understanding of how technology and environmental changes will affect work. Leopold et al. (2018) compared the skills the companies estimated as top ten in 2018 with those estimated for 2022. Table 2 shows the trending and declining skills relative to their prominence in 2018.

There is a fall in demand for manual skills and physical abilities and for skills related to the management of financial and other resources, as well as basic technology installation and maintenance skills (ibid.). Skills that show growing demand for human work by 2022 include analytical thinking and innovation, as well as active learning and learning strategies, technology design and programming. There is also increasing demand for 'human' skills such as creativity, originality and initiative, critical thinking, persuasion, and negotiation, attention to detail, resilience, flexibility and complex problem-solving. Emotional intelligence, 
Table 1. Cluster of 21st century competencies following the National Research Council (2012).

Cluster of Competencies

Main driving factor

Cognitive competencies

- Cognitive processes and strategies: Critical thinking, problem solving, analysis, reasoning/argumentation, interpretation, decision-making, adaptive learning, executive function

- Knowledge: Information literacy (research using evidence and recognizing bias in sources), information and communications technology literacy, oral and written communication, and active listening

- Creativity: Creativity and innovation

Ability factor: fluid intelligence

Ability factor: crystallized intelligence

Ability factor: general retrieval ability

Intrapersonal competencies

- Intellectual openness: Flexibility, adaptability, artistic and cultural appreciation, personal and social responsibility (including cultural awareness and competence), appreciation for diversity, adaptability, continuous learning, intellectual interest and curiosity

Personality factor: openness

- Work ethic/conscientiousness: Initiative, self-direction, responsibility, perseverance, productivity, grit, Type 1 self-regulation (metacognitive skills, including forethought, performance, and self-reflection), professionalism/ethics, integrity, citizenship, career orientation

Personality factor: conscientiousness

- Positive core self-evaluation: Type 2 self-regulation (self-monitoring, self-evaluation, self-reinforcement), physical and psychological health

Personality factor: emotional stability

Interpersonal competencies

- Teamwork and collaboration: Communication, collaboration, teamwork, cooperation, coordination, interpersonal skills, empathy/perspective taking, trust, service orientation, conflict resolution, negotiation

- Leadership, responsibility, assertive communication, self-presentation, social influence with others

Personality factor: extraversion

Table 2. Comparison of top ten demanded skills estimated for 2018 vs. 2022 (Source: Leopold et al., 2018: p. 12).

\begin{tabular}{|c|c|c|}
\hline Today, 2018 & Trending, 2022 & Declining, 2022 \\
\hline - Analytical thinking and innovation & - Analytical thinking and innovation & - Manual dexterity, endurance and precision \\
\hline - Complex problem-solving & - Active learning and learning strategies & - Memory, verbal, auditory and spatial abilities \\
\hline - Critical thinking and analysis & - Creativity, originality and initiative & - Management of financial, material resources \\
\hline - Active learning and learning strategies & - Technology design and programming & - Technology installation and maintenance \\
\hline - Creativity, originality and initiative & - Critical thinking and analysis & - Reading, writing, math and active listening \\
\hline - Attention to detail, trustworthiness & - Complex problem-solving & - Management of personnel \\
\hline • Emotional intelligence & - Leadership and social influence & - Quality control and safety awareness \\
\hline - Reasoning, problem-solving and ideation & - Emotional intelligence & - Coordination and time management \\
\hline • Leadership and social influence & - Reasoning, problem-solving and ideation & - Visual, auditory and speech abilities \\
\hline - Coordination and time management & - Systems analysis and evaluation & - Technology use, monitoring and control \\
\hline
\end{tabular}

leadership and social influence and service orientation will also be in high demand relative to their current position.

Following this analysis, we assume that fundamental cross-contextual and universally applied personality factors and complex, higher level cognitive processes and strategies are central for those 21 st century competencies that are resilient towards automation. Although personality traits such as openness or extraversion are seen as fixed, a literature review by Almlund, Duckworth, Heckman, and Kautz (2011) concluded that personality traits can be modified by experience, education and intervention. Lewin and McNicol (2014) emphasized that ICTs are crucial for the development of 21 st century skills. For example, using digital 
tools improves creativity by providing learners with ways to generate new ideas, new ways of doing things and express themselves in new ways (Lewin \& McNicol, 2014; Van Laar, van Deursen, van Dijk, \& de Haan, 2017). Due to automation, psychomotor skills that do not affect other areas such as the affective area will be in low demand for future human labor.

Synthesizing 21st century skills and the risk of automation, we come to the following heuristic framework of 21st Century Competencies (see Figure 1). In addition to the models of Loshkareva et al. (n.d.) and the National Research Council (2012), we aligned the areas of competencies with the range of applications, the lifetime and the risk of automation. While Loshkareva et al. (n.d.) relate the automation risk to the cognitive, affective and psychomotor domain, we also include the interpersonal domain, for which we assume a higher automation risk compared to the intrapersonal domain, but a similar one compared to the cognitive area. Nevertheless, according to Gold and Bode (2017), social skills will be difficult to replace with technology in the foreseeable future. Digital skills are cognitive skills that are specific to using digital technologies and working in digitized environments. The National Research Council (2012) regards the intrapersonal cluster as Bloom's affective domain, so that we equate the affective area with the intrapersonal one.

Figure 1 shows that the more generalizable a competence is the lower the automation risk and the higher the lifetime of the competence. Furthermore, it becomes salient that the intrapersonal category which includes non-cognitive skills is central for the more generalizable competencies and compared to the cognitive processes and the knowledge cluster of the cognitive category (Loshkareva et al., n.d.) it is most resilient towards automation and digitization. The model offers a general heuristic for the selection of fundamental future pedagogical goals, which are defined as those that are resilient towards automation and digitization and are of high demand for human labor. The National Research Council (2012) does not view the 21st century competencies as new and they do not value them differently compared to the past.

We conclude that higher cognitive processes and strategies, information literacy and information and communication technology literacy, as well as creativity, will play a crucial role for human life and work in the future. Besides, the adult personality becomes an important topic in the future of human life and work. As Bode, Ott, Brunow and Sorgner (2019) showed, “jobs typically held by workers who are more open to experience or emotionally more stable are less susceptible to being replaced by emerging technologies" (p. 28). According to the authors this does also apply to jobs that are typically held by more extraverted or less agreeable staff.

Becker and von den Gracht (2014) postulate that planning and implementation of further education are insufficiently future-oriented. A scientific program for studies concerning the future of (further) education couldn't be established yet. There exists neither a systematic overview of research concerning future 


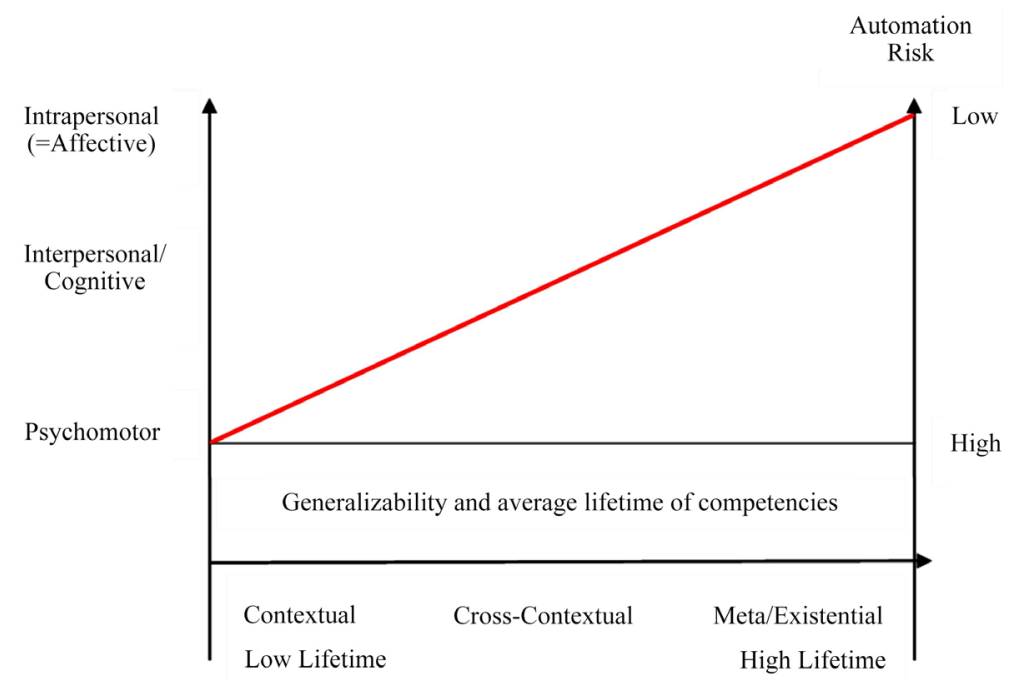

Figure 1. Automation risk of $21^{\text {st }}$ century competencies in relation to generalizability and lifetime of competencies.

studies about training in the German-speaking area, nor one in the English-speaking area. But nevertheless, the importance of this research perspective is recognized: For instance, the Swiss SVEB established a think tank to study the future of adult education. To know about what is likely to continue and what is likely to change in the adult training sector lays a foundation for strategic planning and decision making as well as for future oriented training innovations. Generating knowledge about the future of training is critical for shaping the scenarios of preferred training futures. From a more specific perspective, knowing about future skills and target groups enables trainers, learning managers and politicians to cope with the identified future challenges.

The motif of the present contribution is to give an overview of international studies on the future of training in the form of a systematic review. Here, training refers to the forms of adult training, workforce training and vocational training. The goal is to contribute to the clarification of future training by systematically reviewing literature on target groups, program goals and program elements.

The subordinate research question is: What is known about future training in the scientific literature?

Furthermore, the following sub-research questions are addressed in the article:

1) What are the target groups of future training for adults?

2) What are the goals of future training for adults?

3) What are the program elements of future training for adults?

\section{Method}

The purpose of a review is to systematically extract relevant information from all existing publications devoted to a specific topic. For the selection of the publications, inclusion and exclusion criteria are defined in advance. Our study focuses on problems, target groups, program goals and program elements defined by 
Bullough et al. (2015). Since there are presently no reviews concerning studies of the future of training, in the present study this research question is addressed and is examined using frequency analysis and qualitative methods. According to Flick, von Kardoff, and Steinke (2000), qualitative research is suitable for less thoroughly studied research fields.

\subsection{In- and Exclusion Criteria for Literature Research and Search Strategy}

The search procedure consisted of four steps. In the first step, we selected the databases: Education Resources Information Center (ERIC), as training is a core action of education, and Google Scholar. To specify the search in the second step, the following search criteria were set in ERIC: Search within the 1) full text available on ERIC, 2) Publication type: journal articles, 3) peer reviewed only, and 4) publication date since 2016, to ensure relevance and actuality and 5) find search terms. We searched for articles using the core search terms in the English language: "prospective" AND "vocational training", "prospective" AND "adult training", "prospective" AND "workforce training", "future" AND "vocational training", "future" AND "adult training" and "future" AND "workforce training". The operator used was "AND". To guarantee a precise search and to prevent a time-consuming subsequent audit of full texts available on ERIC, the search terms were placed in quotation marks, e.g. "future" AND "adult training". In Google Scholar, we searched for articles published since 2016 with the key words "the future of training". As we could not automatically select the criteria of publication type, peer review, and full text available in Google Scholar, we had to select these papers by ourselves. In the third step, we checked all the titles and abstracts of the papers according to the predefined inclusion and exclusion criteria (see Table 3 ) that met our research goals and excluded exact duplicates and irrelevant papers from the data set. To identify relevant papers, based on content in the fourth step, we read the content of the remaining papers and reviewed them according to the inclusion and exclusion criteria.

Table 3. Inclusion and exclusion criteria for review.

\begin{tabular}{|c|c|}
\hline Criteria & Indicator description \\
\hline 1 & Relevant are papers that examine the future goals and/or the future program elements of the training of adults. \\
\hline 3 & Irrelevant are articles that examine the future training of graduate or post-graduate students. \\
\hline 4 & $\begin{array}{l}\text { Irrelevant are articles that examine future initial teacher training because of international inconsistencies in the education system, as, } \\
\text { for example, in Germany the traineeship of a teacher ("Referendariat") is not part of CVET. }\end{array}$ \\
\hline 5 & Irrelevant are articles that apply the concept of future in the sense of needed future research/future direction etc. \\
\hline 6 & Irrelevant are articles that examine future Vocational Education and Training (VET). \\
\hline 7 & $\begin{array}{l}\text { Irrelevant are articles that examine the concept of prospective in the sense of "emerging" target groups, such as for example emerging } \\
\text { leaders. }\end{array}$ \\
\hline
\end{tabular}


The research material chosen is mainly characterized by current, peer-reviewed journal articles published between 2016 and 2020. As the topic still is poorly studied, we also refer to future oriented conference proceedings and research reports.

Following Bullough et al. (2015), the program elements are: Evaluation, Trainer, Delivery (e.g. methods and media), Content: curriculum, Wrap-around services (e.g. mentoring, networking, alumni networks), Reputation and trust: trust that community members, potential and current participants have in the integrity and quality of the program, in the program managers' handling of private and sensitive information, and in the safety of participants during programmatic activities, and Governance and operations. We conducted this search, which was done on 7 July 2020, with these inclusion/exclusion criteria (see Figure 2). Moreover, we include one study identified from the reference lists.

\subsection{Selected Studies}

Applying these criteria, we reached a number of 16 selected articles (see Table 4).

Table 4. Included studies.

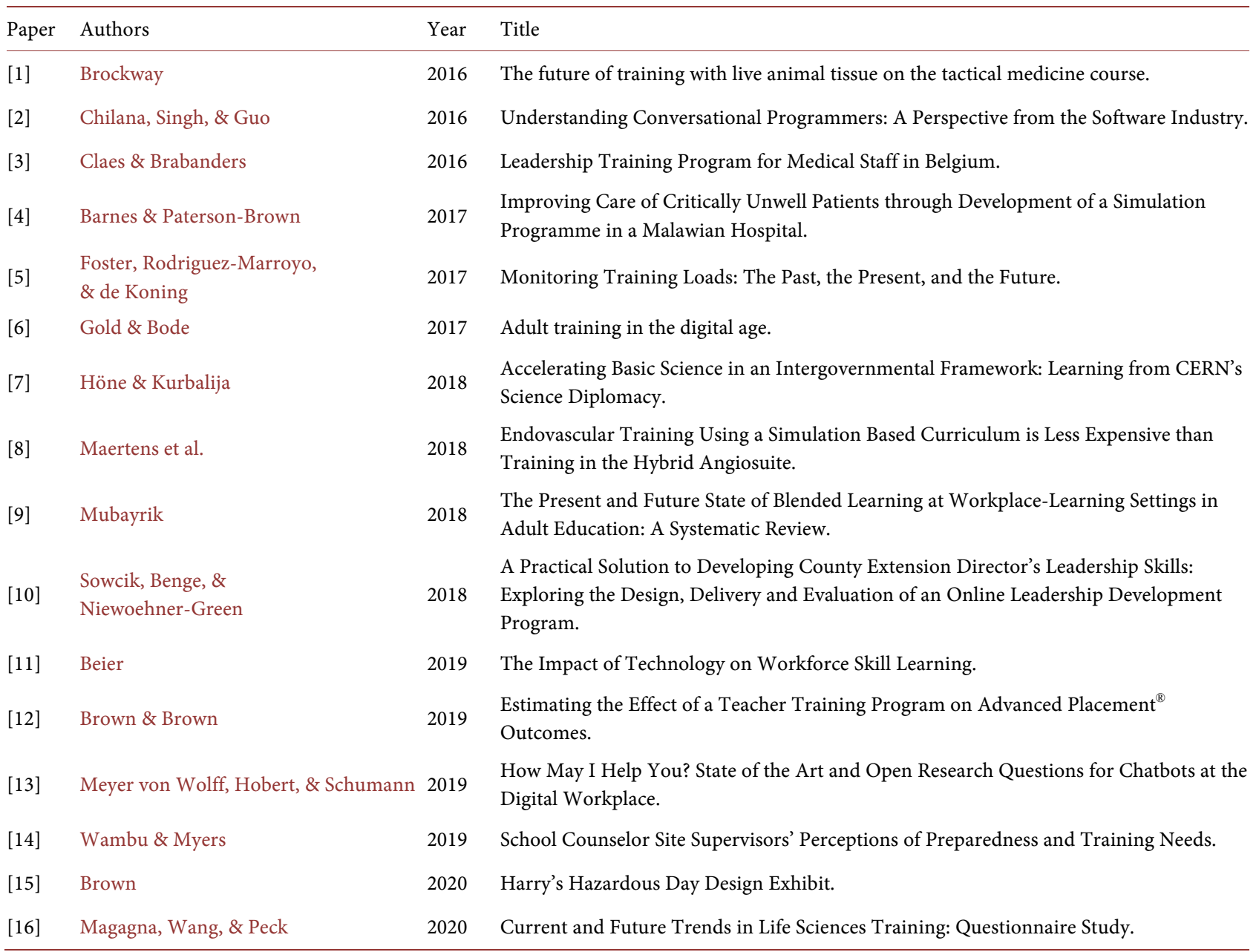


Keywords: "The future of training", "future" AND "vocational training"; "prospective" AND "vocational training"; "future" AND "workforce training"; "future" AND "adult training"; "prospective" AND

"workforce training"; "prospective" AND "adult training".

Formal search criteria: 1

related words applied; 2 )

search within the full text

of the articles; 3 ) full text

available; 4) published

since 2016; 5) academic

journals as a source type.

Criteria: 2), 3), 5) not

selectable in Google

Scholar, to be reviewed

by authors

\begin{tabular}{|l|l}
\hline Databases: & Pape
\end{tabular}

Databases:

Google

Scholar

Review criteria

in: abstracts,

titles,

duplicates

Review

criteria in:

content
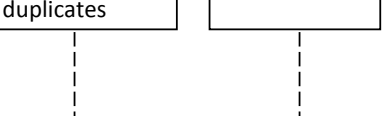

\section{(4)}

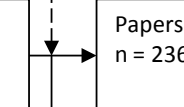

$\underset{\downarrow}{\longrightarrow} \begin{aligned} & \text { Papers } \\ & n=15\end{aligned}$

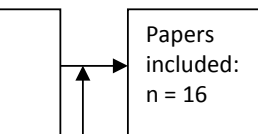

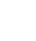

-

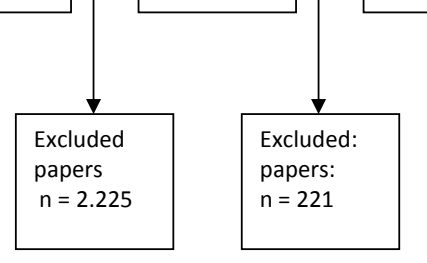

Studies

identified

from the

reference

lists: $\mathrm{n}=1$

Figure 2. Selection procedure of the articles.

\subsection{Analysis of the Data}

As a scientific method, we combined quantitative frequency analysis and qualitative content analysis (Mayring, 2015).

Qualitative content analysis includes different types of analysis procedures such as deductive and inductive analysis. By means of deductive content analysis, categories are derived from theory (Gläser \& Laudel, 2010). In the case of inductive content analysis, the material is consolidated into main messages, and categories emerge from the text over the course of work (Kuckartz, 2010). After the selection of texts, by means of the systematic literature review, we analyzed the data following a deductive content analysis (Mayring, 2015) and an inductive analysis. Text material was coded with deductively formed main categories, and extracts from the texts that were coded into the same category were put together.

\section{Results}

Considering papers from 2016 on with the topic of future training, from the databases ERIC and Google Scholar we cannot specify any trend in terms of frequencies. Surprisingly, based on these databases, no increase in research activity can be identified with the indicator of published papers (see Table 4). Table 5 gives an overview of the problems, target groups and goals of future training.

Tables 6-8 show the theoretically derived coding schemes for the goals and analyzed program elements based on Anderson and Krathwohl (2001), Bullough et al. (2015), Bloom (1956), Loshkareva et al. (n.d.) and Mandl, Friedrich and Hron (1986). The primary focus of the studies regarding the program elements 
were different knowledge types. Less central program elements, such as delivery, governance and operations or evaluation, are summarized in the text. For the problems and the target groups, we applied the inductive analysis (see Table 9, Table 10). Due to the small number of problems and target groups, it would not be efficient to refer to Standard Occupational Classifications (SOC) or to the categorizations of problems.

Table 5. Problems, target groups and program goals of future training.

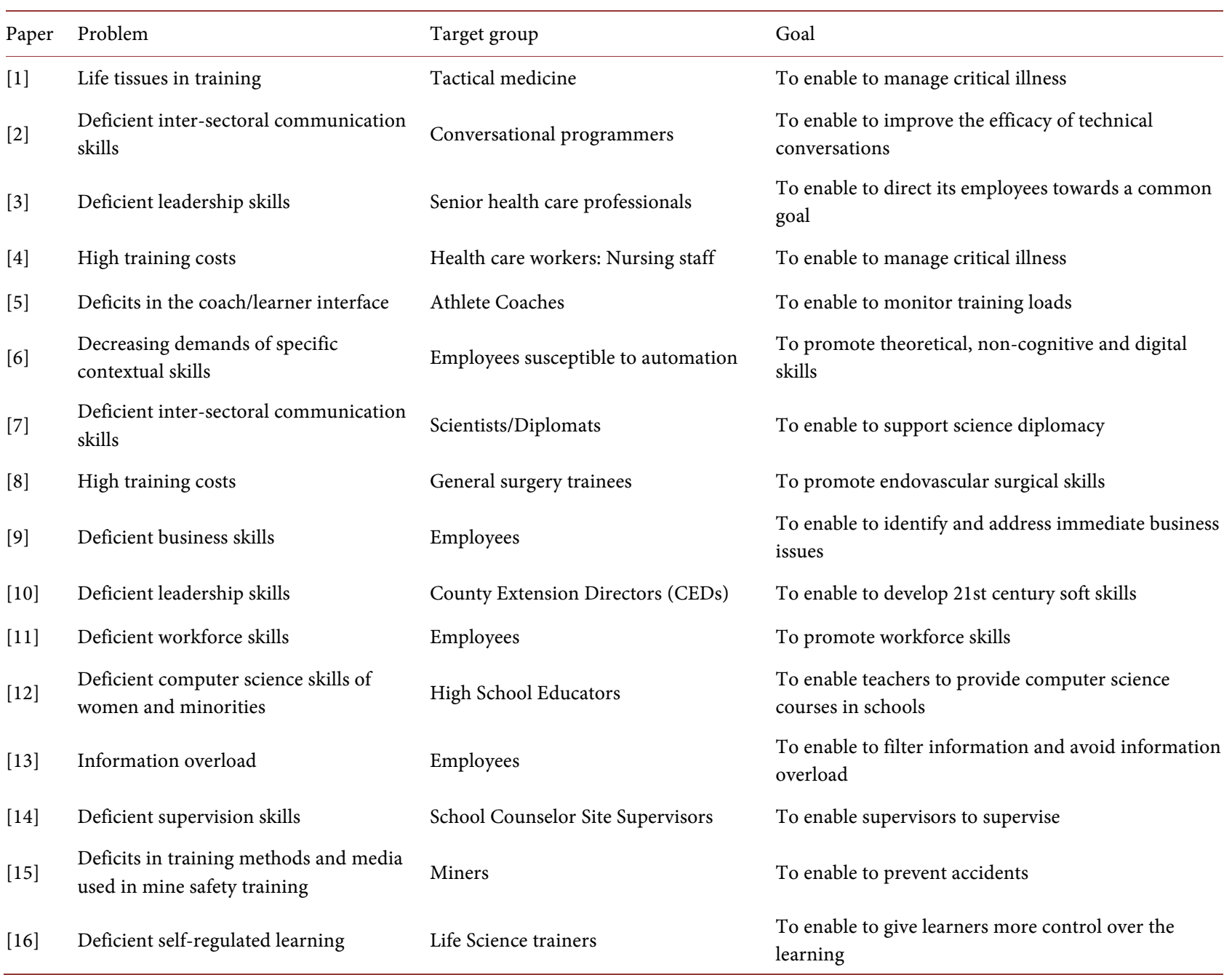

Table 6. Coding scheme for domain of goals.

\begin{tabular}{ll}
\hline Code & Description (Bloom, 1956) \\
\hline Cognitive domain & The cognitive domain includes knowledge, intellectual abilities and skills. To enable to manage illness \\
Psychomotor domain & The psychomotor domain refers to the manipulation of objects. To enable to manage loss of airway \\
Interpersonal domain & $\begin{array}{l}\text { The interpersonal domain relates to the way a person deals with other } \\
\text { persons. }\end{array}$ \\
Intrapersonal (affective) domain & $\begin{array}{l}\text { The intrapersonal domain relates to the way a person deals with things or } \\
\text { interacts with other persons emotionally. }\end{array}$ \\
\hline
\end{tabular}


Table 7. Coding scheme for generalizability of goals.

\begin{tabular}{lll}
\hline Code & Description (Loshkareva et al., n.d.: p. 78) & Example \\
\hline Contextual goals & Contextual goals are related to hard skills developed in a specific context & To enable to drive a car \\
Cross-contextual goals & Cross-contextual skills "can be applied in a larger domain" & To enable to read \\
& $\begin{array}{c}\text { - Meta-skills are "different modes of operating objects in our mind or in the } \\
\text { physical world" }\end{array}$ & • To enable to think in a logical mode \\
Meta/Existential goals & $\begin{array}{l}\text { Existential skills are foundational skills which "can be universally applied } \\
\text { throughout the lifetime and in different living contexts" }\end{array}$ & • To promote willingness to work \\
& &
\end{tabular}

Table 8. Coding scheme for knowledge type.

\begin{tabular}{ccc}
\hline Code & Description (Mandl et al., 1986: p. 145) & Example \\
\hline Declarative knowledge & "Knowledge of facts" & Computer science content \\
Problem solving knowledge & "Knowledge of strategies to master problem situations" & Strategies to manage illness \\
Procedural knowledge & "Knowledge that underlies psychomotoric and cognitive abilities" & Riding a bicycle \\
Meta-cognition & "Knowledge that steers reflection on own knowledge and own actions" Subjective time of carrying out processes \\
\hline
\end{tabular}

Table 9. Inductively derived coding scheme for problems.

\begin{tabular}{ccc}
\hline Code & Description & Example \\
\hline Shortage of skills & The problem refers to deficient skills. & Deficient leadership skills \\
Problem of didactics & The problem refers to the relationship of learning and teaching. & Missing interface between trainer and learner \\
Problem of context & The problem relates to characteristics of the surrounding. & Information overload \\
Problem of financing & The problem relates to high training costs. & High training costs \\
\hline
\end{tabular}

Table 10. Inductively derived coding scheme for target groups.

\begin{tabular}{lll}
\hline Code & Description & Example \\
\hline Health care professionals & $\begin{array}{l}\text { The professionals provide health care treatment and advice based } \\
\text { on formal training. }\end{array}$ & $\begin{array}{l}\text { Nursing staff, health care senior professionals, } \\
\text { general surgery trainees and tactical medicine } \\
\text { Professionals of the }\end{array}$ \\
educational sector & $\begin{array}{l}\text { The professionals provide education including teaching, training, Athletic coaches, high school educators, school } \\
\text { counslling, coaching based on formal training. }\end{array}$ & counselor site supervisors and life science trainers \\
Employees & $\begin{array}{l}\text { The employees are persons who are paid to work for an } \\
\text { organization or another person and whose profession is not }\end{array}$ & Employees of companies \\
mentionaed in the studies. & $\begin{array}{l}\text { This cluster includes these professionals that are not being } \\
\text { included under the health care and educational sectors. }\end{array}$ & Conversational programmers, scientists and \\
Divers & & diplomats, county extension directors and miners
\end{tabular}

The results for the problems, goals and knowledge types based on the coding schemes are presented for each target group cluster in the following tables (Tables 11-14).

For the cluster of health care professionals (see Table 11), consisting of nursing staff, health care senior professionals, general surgery trainees and tactical medicine, the majority of health related goals are context-specific, such as the goal to enable to manage critical illness. The training knowledge is mainly of the declarative, problem solving and procedural type, such as in the case of recognizing 
types of injuries as a precondition for their management. The training typically promotes both cognitive and psychomotor skills, predominantly realized through the didactic method of simulation.

Table 11. Target group cluster: Health Care Professionals.

\begin{tabular}{|c|c|c|c|c|c|c|c|c|c|c|c|c|c|c|}
\hline \multirow[t]{2}{*}{ Paper } & \multicolumn{4}{|c|}{ Problem } & \multicolumn{3}{|c|}{ Domain of goals } & \multicolumn{3}{|c|}{ Generalizability of goals } & \multicolumn{4}{|c|}{ Knowledge type } \\
\hline & 1 & 2 & 3 & 4 & 1 & 2 & 3 & 1 & 2 & 3 & 1 & 2 & 3 & 4 \\
\hline [1] & & + & & & + & + & & + & & & + & + & + & \\
\hline [3] & + & & & & + & + & & + & & & + & + & & + \\
\hline [4] & & & & + & + & & + & & + & & + & + & + & \\
\hline$[8]$ & & & & + & + & + & & + & & & + & + & + & \\
\hline Legend: & $\begin{array}{l}\text { (1) } \mathrm{S} \\
\text { (2) } \mathrm{P} \\
\text { (3) } \mathrm{P} \\
\text { (4) } \mathrm{P}\end{array}$ & $\begin{array}{l}\text { age o } \\
\text { em o } \\
\text { em o } \\
\text { em o }\end{array}$ & $\begin{array}{l}\text { ls } \\
\text { ctics } \\
\text { context } \\
\text { ncing }\end{array}$ & & $\begin{array}{l}\text { Goals re } \\
\text { (1) Cogr } \\
\text { (2) Psyc } \\
\text { (3) Inter } \\
\text { (4) Intra }\end{array}$ & $\begin{array}{l}. . \\
\text { lls } \\
\text { skills } \\
\text { skills } \\
\text { skills }\end{array}$ & & $\begin{array}{l}\text { (1) Con } \\
\text { (2) Cro } \\
\text { (3) Met }\end{array}$ & $\begin{array}{l}\text { al } \\
\text { ntextual } \\
\text { stential }\end{array}$ & & $\begin{array}{l}\text { (1) } \mathrm{De} \\
\text { (2) } \mathrm{Pr} \\
\text { (3) } \mathrm{Pr} \\
\text { (4) } \mathrm{M}\end{array}$ & $\begin{array}{l}\text { cativ } \\
\text { em sc } \\
\text { dura } \\
\text { cogn }\end{array}$ & $\begin{array}{l}\text { g kr } \\
\text { wle }\end{array}$ & ledge \\
\hline
\end{tabular}

Table 12. Target group cluster: Professionals of the Educational Sector.

\begin{tabular}{|c|c|c|c|c|c|c|c|c|c|c|c|c|c|c|c|}
\hline \multirow[t]{2}{*}{ Paper } & \multicolumn{4}{|c|}{ Problem } & \multicolumn{4}{|c|}{ Domain of goals } & \multicolumn{3}{|c|}{ Generalizability of goals } & \multicolumn{4}{|c|}{ Knowledge type } \\
\hline & 1 & 2 & 3 & 4 & 1 & 2 & 3 & 4 & 1 & 2 & 3 & 1 & 2 & 3 & 4 \\
\hline$[5]$ & & + & & & + & + & & & + & & & + & & + & \\
\hline$[12]$ & + & & & & + & & + & & + & & & + & + & & \\
\hline$[14]$ & + & & & & + & & + & + & + & & & + & + & & + \\
\hline$[16]$ & + & & & & + & & & & + & & & & & & \\
\hline Legend: & \multicolumn{3}{|c|}{$\begin{array}{l}\text { (1) Shortage of skills } \\
\text { (2) Problem of didactics } \\
\text { (3) Problem of context } \\
\text { (4) Problem of financing }\end{array}$} & & \multicolumn{3}{|c|}{$\begin{array}{l}\text { Goals related to ... } \\
\text { (1) Cognitive skills } \\
\text { (2) Psychomotor skills } \\
\text { (3) Interpersonal skills } \\
\text { (4) Intrapersonal skills }\end{array}$} & & \multicolumn{2}{|c|}{$\begin{array}{l}\text { (1) Contextual } \\
\text { (2) Cross-contextual } \\
\text { (3) Meta/Existential }\end{array}$} & & \multicolumn{4}{|c|}{$\begin{array}{l}\text { (1) Declarative knowledge } \\
\text { (2) Problem solving knowledge } \\
\text { (3) Procedural knowledge } \\
\text { (4) Meta-cognition }\end{array}$} \\
\hline
\end{tabular}

Table 13. Target group cluster: Employees.

\begin{tabular}{|c|c|c|c|c|c|c|c|c|c|c|c|c|c|c|c|}
\hline \multirow[t]{2}{*}{ Paper } & \multicolumn{4}{|c|}{ Problem } & \multicolumn{4}{|c|}{ Domain of goals } & \multicolumn{3}{|c|}{ Generalizability of goals } & \multicolumn{4}{|c|}{ Knowledge type } \\
\hline & 1 & 2 & 3 & 4 & 1 & 2 & 3 & 4 & 1 & 2 & 3 & 1 & 2 & 3 & 4 \\
\hline$[6]$ & & & + & & + & & + & + & + & & + & + & + & + & + \\
\hline [9] & + & & & & + & & + & & + & & & + & + & & \\
\hline [11] & + & & & & + & & + & & + & & & & & & \\
\hline$[13\}$ & & & + & & + & & & & + & + & & + & & & \\
\hline Legend: & \multicolumn{4}{|c|}{$\begin{array}{l}\text { (1) Shortage of skills } \\
\text { (2) Problem of didactics } \\
\text { (3) Problem of the context } \\
\text { (4) Problem of financing }\end{array}$} & \multicolumn{4}{|c|}{$\begin{array}{l}\text { Goals related to ... } \\
\text { (1) Cognitive skills } \\
\text { (2) Psychomotor skills } \\
\text { (3) Interpersonal skills } \\
\text { (4) Intrapersonal skills }\end{array}$} & \multicolumn{3}{|c|}{$\begin{array}{l}\text { (1) Contextual } \\
\text { (2) Cross-contextual } \\
\text { (3) Meta/ Existential }\end{array}$} & \multicolumn{4}{|c|}{$\begin{array}{l}\text { (1) Declarative knowledge } \\
\text { (2) Problem solving knowledge } \\
\text { (3) Procedural knowledge } \\
\text { (4) Meta-cognition }\end{array}$} \\
\hline
\end{tabular}


Table 14. Target group cluster: Diverse.

\begin{tabular}{|c|c|c|c|c|c|c|c|c|c|c|c|c|c|c|c|}
\hline \multirow[t]{2}{*}{ Paper } & \multicolumn{4}{|c|}{ Problem } & \multicolumn{4}{|c|}{ Domain of goals } & \multicolumn{3}{|c|}{ Generalizability of goals } & \multicolumn{4}{|c|}{ Knowledge type } \\
\hline & 1 & 2 & 3 & 4 & 1 & 2 & 3 & 4 & 1 & 2 & 3 & 1 & 2 & 3 & 4 \\
\hline$[7]$ & + & & & & + & & + & & + & & & + & + & & \\
\hline [10] & + & & & & + & & + & + & + & & + & + & & & + \\
\hline$[15\}$ & & + & & & + & + & & & + & & & + & & + & \\
\hline Legend: & \multicolumn{3}{|c|}{$\begin{array}{l}\text { (1) Shortage of skills } \\
\text { (2) Problem of didactics } \\
\text { (3) Problem of the context } \\
\text { (4) Problem of financing }\end{array}$} & & \multicolumn{3}{|c|}{$\begin{array}{l}\text { Goals related to ... } \\
\text { (1) Cognitive skills } \\
\text { (2) Psychomotor skills } \\
\text { (3) Interpersonal skills } \\
\text { (4) Intrapersonal skills }\end{array}$} & & \multicolumn{2}{|c|}{$\begin{array}{l}\text { (1) Contextual } \\
\text { (2) Cross-contextual } \\
\text { (3) Meta/Existential }\end{array}$} & & \multicolumn{4}{|c|}{$\begin{array}{l}\text { (1) Declarative knowledge } \\
\text { (2) Problem solving knowledge } \\
\text { (3) Procedural knowledge } \\
\text { (4) Meta-cognition }\end{array}$} \\
\hline
\end{tabular}

Correspondingly, characteristic media are patient simulators (e.g. soldier form simulators) which are subject to tablet control, as well as patient dolls and videos. Trainers are recruited from various disciplines and sectors: For leadership training, e.g., some trainers work inside the health sector, such as physicians and health care leaders. Others work outside the health sector, e.g., at faculties of business schools. The wrap-around service is specified in one study as long-term follow-up for securing learning transfer. The program elements of reputation and trust, as well as governance, are not of primary concern in these papers.

The goals and the program elements are related to problems of lacking didactics, skills and funding. In the case of tactical medicine in the battlefield, the didactic problem of working with life tissues in training (Brockway, 2016) is of an ethical nature: This problem is discussed in the frame of optimization of real-life scenarios in simulated environments. Another problem is the deficiency of leadership skills in the health care sector (Claes \& Brabanders, 2016) and negatively affects, for instance, patient care and the motivation of sub-ordinates. Hence, effective leadership programs to develop the skills of future leaders are required. To judge the effectiveness of training, evaluation is crucial. For emergency nursing training, a pre- and post-training self-assessment demonstrates high satisfaction with training and subjective increase in learning (Barnes \& Paterson-Brown, 2017). To compensate the low monetary resources for training in the health sector in developing countries training designers 1) apply inexpensive computerassisted simulation mannequins of an immobile nature as an issue in low resource settings and 2) train future trainers during the training of the target groups, in order to distribute the training regionally (Barnes \& Paterson-Brown, 2017). In industrialized countries simulations play a central role in reducing high training costs in the medical domain: The economic evaluation shows that the costs of high cost endovascular training in the hybrid angiosuite can be reduced using a simulation-based curriculum (Maertens et al., 2018).

Referring to the target group cluster of the education sector (Table 12) with athletic coaches, high school educators, school counselor site supervisors and life 
science trainers, the goals mainly consist of context-specific goals. As education is a social action, pedagogical goals in the education sector are of an interpersonal nature. These goals also address promoting cognitive skills, as education consists of learning subjects, such as, e.g., enabling to understand ethical issues of supervising. Declarative and problem solving knowledge are the predominant knowledge types. Delivery includes primarily activating learning methods in which content-based social skills can be practiced. Media are especially learning technologies, such as wearable sensors and software and hardware of virtual reality. Trainers are from the education sector in which they are charged with tasks of education and education management. Building online learning communities characterizes the wrap-around service of one training program.

The program goals are mainly related to lack of skills: The deficient skills of women and minority students in STEM fields and computer science result from the significant under-representation of pupils in these courses (Brown \& Brown, 2019). Targeted training of teachers to provide computer science courses already in school should increase the number of female and minority students enrolled in advanced computer science courses (Brown \& Brown, 2019). The evaluation format of this training shows that targeted measures can yield tangible results. Brown and Brown (2019) estimated the effect of program participation of high school educators on the participation of their pupils in test taking and on the qualifying score earned by pupils in computer science courses. In the field of school counseling inadequate standards for training contribute to a shortage of skills (Claes \& Brabanders, 2016; Wambu \& Myers, 2019): In the foreseeable future standardized training realized by professional associations is needed. To meet the trending skills of active learning and to give learners more control over learning (Magagna et al., 2020), the understanding of the trainer is changing towards a content curator and simulation and creation tools are used more frequently. A didactic problem is presented by the matching between training load and individual performance that is to be optimized: The central starting points here are learning technologies (athletic coaching) (Foster et al., 2017), which make essential personal achievement parameters visible and are to be researched further in the future.

Table 13 shows that the goals for the non-specified cluster of employees address especially cognitive and interpersonal skills. Employees highly susceptible to automation and employees in general belong to this target group. Contextual skills, such as promoting workforce skills, can be regarded as prevalent. Besides cross-contextual skills, like filtering information, and meta-skills like promoting willingness to learn are mentioned but are less important than contextual skills. Declarative and problem solving knowledge are of great importance in this sector. The definition of the target group of employees that is highly susceptible to automation results from changing work conditions. Skills that are resilient towards automation are seen in theoretical, non-cognitive and digital work environments. In an information society, the pedagogical goal to enable learners to 
filter information and to avoid information overload has increasing importance. This goal was addressed via chat bots that answer questions in a personalized way. Blended learning formats and learning technologies are the central methods and media for this cluster. In terms of governance and operation, the training program for employees highly susceptible to automation is seen not only as an important matter of national concern that requires a legal framework, but also as one of G20 countries.

The central problems are posed by the automation of specific skills and of information overload. For training that promotes theoretical, non-cognitive and digital skills of employees highly susceptible to automation (Gold \& Bode, 2017), the importance of the program elements of Governance and Operation and Funding stand out. In view of the importance of this training, the authors postulate that the G20 states initiate this program and national legal frames for executing it are pre-given. The governments could fund this program. The other central problem is that employees spend an increasing amount of time in searching, editing or sharing information, which could have a negative impact on employees' productivity. The problems of the wealth of information and information overload should be coped with by artificial intelligence (Meyer von Wolff et al., 2019), in that information will be made available in a personalized, need oriented manner. No evaluations are available for the training carried out in this sector.

For the diverse target group cluster (see Table 14), including conversational programmers, scientists and diplomats, county extension directors and miners, we find especially cognitive and interpersonal domains of goals. The interpersonal skills of this cluster have in common that they enable learners to improve communication between professionals of different sectors, such as scientists and diplomats. The need for inter-sectoral communication results in a newly defined target group of conversational programmers. Contextual goals are the dominant goals in this cluster. Correspondingly, declarative and problem solving knowledge are critical to these goals. A didactic method in this cluster is the serious game for safety training that allows real users and bots to act together. Via the game's dashboard, the learner and trainer personalize the learning process by reconstructing the interactions, decisions, speed and outcome of each learner and the feedback, including introduced job action sheets and improvement plans. The evaluation of the learning process is realized via the advanced analytic capabilities of the game system. The performance statistics include results of cohort, crew, organizational and individual levels. The evaluation of the cost efficient online leadership program targeted at country extension directors demonstrates the participants' satisfaction with the training, their perceived learning to impact leader self-confidence, and behavior change of different leadership competencies (Sowcik et al., 2018). Typical problems in this sector are the lack of skills in leadership competencies in the country extension sector (Sowcik et al., 2018) or in the inter-sectoral communicative competencies (Chilana et al., 2016; Höne \& Kurbalija, 2018). Accordingly the training focuses on the goals of promoting peaceful 
relations and furthering strategic and national research interests, as, e.g., in the case of diplomats and scientists, or in the case of conversational programmers, the goal to develop conversational skills in programming literacy to be able to 1 ) aid technical conversations with professional software developers in the future; or 2) enhance their marketability in the software industry.

\section{Discussion and Conclusion}

Based on the literature review, we conclude that the analyzed studies investigating the future of training address goals that promote demanded skills in the foreseeable future. To these skills belong psychomotor skills in close connection with cognitive skills such as needed in the medical sector, interpersonal skills including leadership skills and skills of communicating intersectorally, learning skills, as well as theoretical and non-cognitive skills. The majority of the goals are related to context-specific skills such as, for example, the ability to promote digital skills.

The goals come from fundamental problems that are critical in the foreseeable future: They refer to 1) didactic problems such as deficient interface between trainer and learner, and ethical problems such as use of life tissue, to 2) shortages of skills, such as interpersonal skills, 3) problems of context, such as decreasing demands for skills or information overload, and 4) problems of finances, such as low resources for training in developing countries.

The prevalent knowledge types related to the identified goals are declarative, procedural and problem solving knowledge. Correspondingly, besides instruction, provision in terms of didactic methods is typically realized through activating methods that are also close to reality, such as simulation, games, case studies and role playing games. Characteristic media are learning technologies such as simulators which are under tablet control, patient dolls and videos, wearable sensors, software and hardware of virtual reality and artificial intelligence. Trainers of a training program are typically recruited from various disciplines and sectors. In terms of funding and support, evaluation formats referring to performance measures and the measurement of results are of increasing importance.

This paper thus provides an overview of the skill-related needs of future adult trainings for different target groups. In connection with this, particularly suitable methods of implementation are named for achieving the respective goals. For practitioners, the findings provide a basis for the conception of trainings for executives and employees.

In terms of research desiderata, we identify a research gap in promoting intrapersonal skills that are more generalizable and most resilient towards automation and digitization. Meta- and existential skills are not in the focus of the analyzed studies of future training. Accordingly, there is a lack of research in terms of the meta-cognition knowledge type. Another research gap can be found in the missing program of promoting theoretical and non-cognitive skills for the target group of employees highly susceptible to automation. In terms of quality assur- 
ance, the evaluation of only a few of the presented training programs referring to the level of behavior and results demonstrates that the evaluation of all four levels of the Kirkpatrick model is still a challenge.

Guided learning in the form of training specifically addresses the kind of behavior which consists of a sequence of actions carried out in a precisely stipulated manner, such as for example driving a car. There is a need to discuss whether training defined as non-intended, guided learning (Steiner, 1988) will promote the most generalizable intrapersonal skills, the meta- and existential skills which will be of relevance in the foreseeable future.

The current study is limited especially by the search strategy: By defining keywords for the literature research (see Figure 2), only a mere fraction of the existing literature on the topic of the future of adult training was sighted and analyzed. In future studies, more keywords should be included in the searching process.

\section{Conflicts of Interest}

The authors declare no conflicts of interest regarding the publication of this paper.

\section{References}

Acemoglu, D. (2002). Technical Change, Inequality, and the Labor Market. Journal of Economic Literature, 40, 7-72. https://doi.org/10.1257/jel.40.1.7

Acemoglu, D., \& Autor, D. (2011). Skills, Tasks and Technologies: Implications for Employment and Earnings. In D. Card, \& O. Ashenfelter (Eds.), Handbook of Labor Economics Vol. 4, Part B (pp. 1043-1171). Amsterdam: Elsevier. https://doi.org/10.1016/S0169-7218(11)02410-5

Almlund, M., Duckworth, A. L., Heckman, J., \& Kautz, T. (2011). Personality Psychology and Economics. In E. A. Hanushek, S. Machin, \& L. Woessmann (Eds.), Handbook of the Economics of Education Volume 4 (pp. 1-181). Amsterdam: Elsevier. https://doi.org/10.3386/w16822

Anderson, L. W., \& Krathwohl, D. R. (2001). A Taxonomy for Learning, Teaching, and Assessing: A Revision of Bloom's Taxonomy of Educational Objectives. New York: Longman.

Attwell, G. (2007). Personal Learning Environments-The Future of e-Learning? e-Learning Papers, 2, 1-8.

Barnes, J., \& Paterson-Brown, L. (2017). Improving Care of Critically Unwell Patients through Development of a Simulation Programme in a Malawian Hospital. Journal of Education and Training Studies, 5, 90-96. https://doi.org/10.11114/jets.v5i6.2366

Becker, M., \& von den Gracht, H. (2014). Lernen im Jahr 2030: von Bildungsavataren, virtuellen Klassenräumen und Gehirn-Doping in der Führungs-und Fachkräfteentwicklung: Szenarien auf Basis einer Delphi-Experten-Befragung. Berlin: Institute of Corporate Education e.V.

Beier, M. E. (2019). The Impact of Technology on Workforce Skill Learning. Work Science Center Thinking Forward Report Series. https://smartech.gatech.edu/bitstream/handle/1853/61063/beier thinking forward.pdf

Bloom, B. S. (1956). Taxonomy of Educational Objectives: The Classification of Educational Goals: Handbook I Cognitive Domain. London: Longmans. 
Bode, E., Ott, I., Brunow, S., \& Sorgner, A. (2019). Worker Personality: Another Skill Bias beyond Education in the Digital Age. German Economic Review, 20, e254-e294. https://doi.org/10.1111/geer.12165

Brezinka, W. (1981). Erziehungsziele, Erziehungsmittel, Erziehungserfolg: Beiträge zu einem System der Erziehungswissenschaft. München: Ernst Reinhardt Verlag.

Brockway, W. F. A. (2016). The Future of Training with Live Animal Tissue on the Tactical Medicine Course. Unpublished Service Paper, North York: Canadian Forces College.

Brown, L. D. (2020). Harry's Hazardous Day Design Exhibit. White Paper, Tucson, AZ: University of Arizona.

Brown, R. S., \& Brown, E. A. (2019). Estimating the Effect of a Teacher Training Program on Advanced Placement ${ }^{\star}$ Outcomes. International Journal of Computer Science Education in Schools, 2, 1-16. https://doi.org/10.21585/ijcses.v2i4.35

Bullough, A., De Luque, M. S., Abdelzaher, D., \& Heim, W. (2015). Developing Women Leaders through Entrepreneurship Education and Training. Academy of Management Perspectives, 29, 250-270. https://doi.org/10.5465/amp.2012.0169

Chilana, P. K., Singh, R., \& Guo, P. J. (2016). Understanding Conversational Programmers: A Perspective from the Software Industry. Proceedings of the 2016 CHI Conference on Human Factors in Computing Systems, San Jose, 7-12 May 2016, 1462-1472. https://doi.org/10.1145/2858036.2858323

Claes, N., \& Brabanders, V. (2016). Leadership Training Program for Medical Staff in Belgium. International Journal of Higher Education, 5, 281-287. https://doi.org/10.5430/ijhe.v5n4p281

Flick, U., von Kardorff, E., \& Steinke, I. (2000). What Is Qualitative Research? An Introduction to the Field. In U. Flick, E. von Kardorff, \& I. Steinke (Eds.), A Companion to Qualitative Research (pp. 3-12). London: Sage Publications.

Foster, C., Rodriguez-Marroyo, J. A., \& De Koning, J. J. (2017). Monitoring Training Loads: The Past, the Present, and the Future. International Journal of Sports Physiology and Performance, 12, S2-2-S2-8. https://doi.org/10.1123/IJSPP.2016-0388

Gläser, J., \& Laudel, G. (2010). Experteninterviews und qualitative Inhaltsanalyse. Wiesbaden: VS Verlag für Sozialwissenschaften. https://doi.org/10.1007/978-3-531-91538-8

Gold, R., \& Bode, E (2017). Adult Training in the Digital Age (pp. 1-10). Economics Discussion Papers 2017-54.

Höne, K. E., \& Kurbalija, J. (2018). Accelerating Basic Science in an Intergovernmental Framework: Learning from CERN's Science Diplomacy. Global Policy, 9, 67-72. https://doi.org/10.1111/1758-5899.12589

Kuckartz, U. (2010). Einführung in die computergestützte Analyse qualitativer Daten. Wiesbaden: VS Verlag für Sozialwissenschaften. https://doi.org/10.1007/978-3-531-92126-6

Leopold, T. A., Ratcheva, V. S., \& Zahidi, S. (2018). The Future of Jobs Report 2018. Köln: World Economic Forum.

Lewin, C., \& McNicol, S. (2014). Supporting the Development of 21st Century Skills through ICT. In T. Brinda, N. Reynolds, R. Romeike, \& A. Schwill (Eds.), KEYCIT 2014: Key Competencies in Informatics and ICT (pp. 181-198). Potsdam: University Press.

Loshkareva, E., Luksha, P., Ninenko, I., Smagin, D., \& Sudakov, D. (n.d.). Skills of the Future. How to Thrive in the Complex New World.

http://www.globaledufutures.org/images/people/GEF Skillsofthefuture report.pdf 
Maertens, H., Vermassen, F., Aggarwal, R., Doyen, B., Desender, L., Van Herzeele, I. et al. (2018). Endovascular Training Using a Simulation Based Curriculum Is Less Expensive than Training in the Hybrid Angiosuite. European Journal of Vascular and Endovascular Surgery, 56, 583-590. https://doi.org/10.1016/j.ejvs.2018.07.011

Magagna, W., Wang, N., \& Peck, K. (2020). Current and Future Trends in Life Sciences Training: Questionnaire Study. JMIR Medical Education, 6, e15877. https://doi.org/10.2196/15877

Mandl, H., Friedrich, H. F., \& Hron, A. (1986). Psychologie des Wissenserwerbs. In B. Weidenmann, A. Krapp, M. Hofer, G. L. Huber, \& H. Mandl (Eds.), Pädagogische Psychologie (pp. 143-218). München: Urban \& Schwarzenberg.

Mayring, P. (2015). Qualitative Inhaltsanalyse: Grundlagen und Techniken. Weinheim: Beltz. https://doi.org/10.1007/978-3-531-18939-0 38

Meyer von Wolff, R., Hobert, S., \& Schumann, M. (2019). How May I Help You? State of the Art and Open Research Questions for Chatbots at the Digital Workplace. Proceedings of the 52nd Hawaii International Conference on System Sciences, Maui, 8-11 January, 95-104. https://doi.org/10.24251/HICSS.2019.013

Mubayrik, H. B. (2018). The Present and Future State of Blended Learning at WorkplaceLearning Settings in Adult Education: A Systematic Review. Journal of Social Studies Education Research, 9, 247-273.

National Research Council (2012). Education for Life and Work: Developing Transferable Knowledge and Skills in the 21st Century. Washington DC: The National Academies Press.

Sowcik, M., Benge, M., \& Niewoehner-Green, J. (2018). A Practical Solution to Developing County Extension Director's Leadership Skills: Exploring the Design, Delivery and Evaluation of an Online Leadership Development Program. Journal of Agricultural Education, 59, 139-153. https://doi.org/10.5032/jae.2018.03139

Steiner, E. (1988). Methodology of Theory Building. Sydney: Educology Research Associates.

van Laar, E., van Deursen, A. J. A. M., van Dijk, J. A. G. M., \& de Haan, J. (2017). The Relation between 21st-Century Skills and Digital Skills: A Systematic Literature Review. Computers in Human Behavior, 72, 577-588. https://doi.org/10.1016/j.chb.2017.03.010

Wambu, G. W., \& Myers, C. E. (2019). School Counselor Site Supervisors' Perceptions of Preparedness and Training Needs. Journal of School Counseling, 17, 1-30. 